Article

\title{
Disciplinary History and the Situation of History Teachers
}

\author{
Michael Fordham \\ Corpus Christi College, Cambridge University, Cambridge, CB2 1RH, UK; \\ E-Mail: maf44@cam.ac.uk; Tel.+44-1954-712615
}

Received: 29 September 2012; in revised form: 19 November 2012 / Accepted: 26 November 2012 /

Published: 5 December 2012

\begin{abstract}
A growing consensus in the history education community supports the idea that the discipline of history provides the best opportunity for moving beyond a "nation-building" or "skills-based" approach to teaching about the past. The social and temporal characteristics of the discipline of history mean such conclusions have important implications for teachers of history who must engage with that academic discipline when designing lessons for their pupils. In order to understand the process by which such a curriculum approach might be effected, it is necessary to posit a relationship between history teachers and the discipline of history that rests upon a theoretical model in which history teachers are understood both to represent and embody the discipline of history when teaching their pupils.
\end{abstract}

Keywords: history education; teacher knowledge; sociology of knowledge

\section{Introduction}

One knows that something is afoot when the postmodern critique of history is being cited in the House of Lords [1]. The last three years have, in England, seen a resurgence of interest in the teaching of history in schools, driven by a government that has committed itself to changing what it perceives as a situation in which children in the country do not, it is accused, learn "our island story" [2]. Calls such as this, to use history in schools as the basis for developing a national identity and recognition of common heritage, are near-ubiquitous in political and media commentaries on history teaching. As Cannadine, Keating and Sheldon's recent research showed, this obsession with the history curriculum and its role in nation-building is neither new nor unusual; indeed history has been vehemently debated as a school subject for about as long as compulsory schooling has existed within the United Kingdom [3]. Nor is this 
debate a British peculiarity; arguments about what is included in the history curriculum and how history should be taught can be found across the globe [4]. Moving these debates forward has thus become a concern of history educationalists worldwide [5,6].

The focus on creating such progress in this debate has, quite understandably, focused either on the structure of the curriculum used or it has studied pupils and their understandings of history; in some notable cases educationalists have done both [7]. I would argue, however, that there has been a relative paucity in studies of the very people who are most important in the implementation of changes to history education: the history teachers themselves. Studies have been made of non-specialists teaching history but it is my intention here to focus on those history teachers who are subject specialists, typically through having completed an undergraduate or postgraduate degree in the discipline [8]. Even in situations where curricula are heavily prescribed, such specialist teachers have considerable freedoms to determine how pupils learn their subject through making decisions about the structure of lessons, the way in which different content areas are juxtaposed and framed, and the tasks and activities by which the pupils will come to know the subject. Teaching is, of course, a creative process; teachers are designers and they, perhaps, have more of a role in determining a pupil's understanding of the past than any other factor [9]. For this reason, those teachers must be seen as the lynchpin on which considerations of history education must be understood; no amount of curriculum design at a national level will remove the overriding influence of teachers on the reality of learning history [10].

It is, therefore, my intention here to consider what changes have and are being implemented to the way history is taught, with a particular focus on developments in England. My emphasis, however, is not so much on how the history curriculum might be reformed, but rather on what understandings are required of how history teachers operate in order for the implementation of such change to be possible. My argument here proceeds in four stages. I accept, drawing upon an increasingly wide-ranging academic and professional discourse, that a move beyond either a "nation-building" or "skills-based" conception of history education depends upon founding understandings of the school subject upon the academic discipline of history. Such a framing, I suggest, raises challenges for curriculum theorists, policy makers and, not least, the teachers themselves, because an academic discipline has both social and temporal characteristics that must be understood and reflected in practice. In particular, I argue, an acceptance of the social and temporal character of disciplinary knowledge requires a reconceptualisation of what is understood by "teacher knowledge" and what expectations of history teachers might be required for a discipline-grounded model of history education to be effected. For this to be possible, finally, I propose that history teacher knowledge has to be understood in relational terms; history teachers must be situated, both temporally and socially, in relation to the discipline which they aim to teach.

\section{The Academy and the Classroom}

Space here prevents a developed description of the arguments about the nature of history: in a sense "historical epistemology" has become a field in its own right. At heart this debate concerns the extent to which knowledge of the past is possible and, if it is possible, then what the nature of the explanation of that past might, could or should be like. The question is, of course, ancient: both Herodotus and Thucydides advanced theories of history that, in different ways, were challenges to the blurring of 
history and myth. The origins of the modern discipline are often situated in nineteenth-century Germany where the empiricism of historians such as von Ranke set the example which subsequent generations of historians were to follow, with most practising historians in the twenty-first century adhering, whether actively or passively, to a conception of the historical process by which, through the close analysis of (usually textual) sources, the past might be, to some or other degree, described wie es eigentlich gewesen [11]. Across the twentieth century, this understanding of history was challenged, though never fatally undermined, from a number of angles. Perhaps most significant of the challenges that emerged in the later twentieth century was the loosely-collected set of ideas that is frequently labelled, often disparagingly, as "postmodern". It is, arguably, wrong to pigeon-hole writers in this way, though a number of common ideas characterise these writings, such as a greater emphasis on relativism, subjectivity and plurality in historical explanation. In particular, these arguments challenge the understanding that it is possible to construct a single, empirically-sound, objective account of the past, such as a national grand narrative that might be taught in schools. It is unsurprising that "postmodernism" was the bogeyman of a House of Lords debate on the teaching of "Our Island Story".

Writings about the practice of history are often focused on the historian's method, usually on the understanding that, as in the natural sciences, method is the sine qua non of objectivity. As such, the articulation of a clear and consistent method might be the grounds on which historical objectivity might be achieved, or the uncovering of the multifarious and, at times, personal nature of historical research might be the basis on which objectivity might be challenged. In England, this focus on method has been highly influential in thought about how history might be taught, both in school and at a higher level. Early commentators, such as Keating, were keen to incorporate lessons on the use of sources and other historical methodologies, including archaeology, into the classroom [12]. This was, however, the exception to most pupils' Gradgrindian experience of learning history, and it was not until the 1970s, with the influence of the Schools' Council History Project, that an increasing number of children in the UK had the opportunity to think explicitly and critically about the method by which historical conclusions are reached [13]. The success of this approach meant that for the last part of the twentieth century most pupils spent a considerable amount of their time in history classroom analysing sources and, particularly after 1991, thinking about the status of interpretation in history [12]. This emphasis on developing historical skills challenged the idea that there was one national narrative that needed to be learned, and the "skills-based" approach to learning history thus became the target of vehement critique from those who wanted such a narrative in schools.

The tired debate about "knowledge" versus "skills" is now well trodden, the debate itself increasingly seen as missing the point [14]. Although the debate in the British media and amongst most politicians continues to take this form, history teachers and educationalists have since sought to move beyond this distracting dichotomy and to find some other basis on which an education in history might be based. An approach was needed which allowed for the recognition that a single, uncontested narrative is neither possible nor desirable, without reducing the study of history to the study of the processes by which the past might come to be understood. The most influential response to this challenge is that which proposes grounding history education on a clear sense of disciplinary history. The Usable Historical Pasts project is the latest product of a strong research tradition that has sought to articulate what such an approach might look like [15]. In particular, as Lee argued, it would seem important, if history education is to be driven forwards, that teachers have to give pupils "not a preformed grand narrative, but an apparatus for 
making sense of what narratives are and do in history [16]." This finds realization in a use of "frameworks" that incorporate disciplinary concepts such as historical change, provide overviews consisting of patterns that are revisited and reformulated over time, and resist the idea that the history of any particular place or group can be disconnected from a wider history of humanity [16]. The opportunities offered by such an approach were highlighted by Howson, who saw that the "potential for great achievements in history education on a wide scale is likely to be realised through an increasingly sophisticated disciplinary understanding applied to a progressive framework structure which in turn will allow for complex 'big pictures' of the past — ones that are usable for orientation and allow children to fathom and explain their world in the present and consider what the future might hold [17]."

The idea of placing the discipline at the heart of an education in history, and thus escaping the nation-building or skills-based approaches with all their associated problems, has proven influential. Recent iterations of the National Curriculum have placed the "key concepts" of history, such as "causation", "change" and "significance" at their heart. Similar approaches to teaching history as a discipline are playing a crucial role in developing the teaching of history in a number of other countries, with the work of Seixas in Canada perhaps being the most developed [18]. Probably the greatest signifier of the success of the "concept-based" approach to history can be seen in the published discourse of practising history teachers where numerous schemes of work, often very carefully theorized, show the practical applicability of this approach to teaching history [10]. There are numerous examples now of how teachers have been able to draw upon the concepts which underpin the discipline of history to construct enquiries, sequences of lessons which answer an overarching "enquiry question" with a meaningful outcome task, for their pupils [19]. For our purposes here, most important of all is that underpinning this work is an understanding of "discipline": the key concepts, such as causation, change and continuity, are powerful because they describe the kinds of questions that might be understood as historical. It is this which makes such an approach a strong alternative to a "nation-building" or "skills-based" approach to teaching history. Although disciplinary concepts and skills are often conflated in popular commentary, it is important to maintain a distinction between the two: the concepts of the discipline indicate what might be appropriate historical questions to ask about the past, whereas skills are the means by which one might address those questions [20]. It is, perhaps, due to the clarity with which disciplinary concepts direct the study of the past that has proven most useful to history teachers, allowing them to construe the discipline of history as the kernel of what happens in the history classroom.

\section{The Social and Temporal Nature of Disciplinary Knowledge}

It would seem, therefore, that there is widespread support, at least among the history education community, for the argument that a notion of discipline might serve as the basis for moving history teaching beyond the limitations of "our island story" without slipping into a "skill-based" curriculum that undermines the importance of studying history in its own right. In considering the implications of this, one should reflect on what a discipline actually is. Most arguments for a discipline-based approach to history teaching have emphasised the importance of disciplinary concepts and methods in formulating an understanding of the past. These concepts and methods, of course, are embodied in the practices of 
academic historians. Rules, or at the very least expectations, about the use of source material, for example, govern whether or not an academic work might be accepted for publication. In submitting research proposals, historians are likely to define the questions they wish to ask in conceptual terms: why did an event happen? What were the consequences of an event? To what extent did something change? Historians might, of course, disagree about the rules and concepts governing their discipline, but what matters is that there is a recognized field in which those debates can take place. Importantly, this implies that history, as an academic discipline, is what Durkheim called a "collective representation". For Durkheim, "collective representations are the product of an immense cooperation that extents not only in space but also through time; to make them, a multitude of different minds have associated, intermixed and combined their ideas and feelings; long generations have accumulated their experience and knowledge. A very special intellectuality that is infinitely richer and more complex than that of the individual is distilled in them [21]." Durkheim neatly encapsulates here the fact that an academic discipline, such as history, is both a social and temporal phenomenon. It is worth dealing with these two disciplinary dimensions in turn.

The discipline of history is a social phenomenon because its existence is predicated on the existence of a community. Popper, perhaps most vividly, took the example of Robinson Crusoe. Even if, Popper argued, Crusoe had spent his years in isolation developing scientific knowledge, his new knowledge would not be understood as such until he had returned to society and convinced a body of recognized experts, the crucible of academic critique, that his knowledge was, in fact, knowledge [22]. In some ways this idea has more recently been developed by Lave and Wenger, who argued that knowledge is only meaningful when situated within a "community of practice" and that "participation in the cultural practice in which any knowledge exists is an epistemological principle of learning [23]." Academic knowledge is not solipsistic because it is never just about the knowledge of an individual, but rather exists as a collection of individual claims to knowledge that are submitted to the scrutiny of recognized experts. One might, of course, suggest that this "recognized authority" might simply reflect power relations in society, and indeed the piercing challenge of critical theory offers this kind of analysis. This is a significant challenge, but it is important not to let it run too far. As the advocates of social realism have recently advanced, academic knowledge is not simply the whim of a powerful group in society as it is also "constituted by the objects [academics] seek to study [24]." If a relationship is to be posited between the discipline of history and the school subject, then it would seem necessary to postulate a relationship between history teachers and this disciplinary community.

In accepting that disciplinary knowledge is social, one is required to accept that it is also temporal as the disciplinary communities on which that knowledge depends exist with their own temporal dimension. When a historian writes, they do so not from some tabula rasa, but in the knowledge of what other historians have written before. One could not, for example, study the statesmanship of Offa of Mercia without reference to the work of Stenton, nor could one research the causes of the English Civil War without engaging with the arguments of Hill, even though in both cases those interpretations have been challenged. The modern use of such prior work is critical in nature; past authorities are there to be challenged and not accepted as dogma. Yet it is certainly the case that past claims to knowledge are the starting point from which new research might begin. In Skinner's terms, a writer "must have meant the work as an attack on, or a defence of, as a criticism of, or as a contribution to, some particular attitude or line of argument [25]." It is in this sense that the "canon" of past claims to knowledge is productive. 
In the words of Moore, "the canon enables a particular type of activity and its principles are generative - it is the arena of endless dispute... Judgements are less than absolutes in that they acknowledge their fallibility. They are more than preferences in that they submit themselves to historically evolved rules of collective evaluation [21]." Importantly, the existence of a "canon", which in the discipline of history is often referred to as the "historiography", is not a limitation of disciplinary knowledge: it is a condition of it. Just as a social conception of the discipline requires teachers to relate to the disciplinary community, so too does the discipline's temporal dimension demand an engagement with what has previously been written on any particular subject.

\section{Classroom Implications}

Arguments advanced in the field of history education for placing a notion of discipline at the heart of the school curriculum appear convincing, but it should now be clear that such a framing requires a consideration of the temporal and social character of historical knowledge. This is important for it is has implications for classroom practice. Take, for example, an enquiry question which can be found in classrooms across the UK: why was the British slave trade abolished in 1807? Those familiar with the debate will recognise the historiography: the primacy of "saints" such as Wilberforce and Clarkson, as advanced by Coupland; the centrality of economics, as argued by Williams; the role played by slave rebellions, advanced by Hart; the role played by popular support for abolition in Britain, more recently argued by Drescher [26-28]. Where, in this debate, should pupils begin? As an old and much-challenged interpretation, is it worth examining the views of Coupland? Or can something be gained and understood, both about the question at hand and the way in which history works, by beginning with him? Or ending with him? In planning a sequence of lessons to guide pupils to answering the enquiry question, a history teacher clearly has to reflect carefully not just on the substance of what is studied, important as that is, but also on the way in which that question has already been approached within the discipline.

Examples of how teachers have approached this in practice, revealing the disciplinary thinking that takes place in the enquiry- and lesson-design process, are increasingly available in the published discourse of history teachers [10]. Take, for example, Foster's recent work on the different ways in which two historians dealt with the issue of ordinary German culpability for the Holocaust [29]. Foster described how she spent time developing pupils' substantive knowledge of the past, but throughout she emphasized with her pupils the fact that, historiographically, the events in question had been interpreted in different ways. Foster was particularly keen to demonstrate the way in which two historians had made quite different readings of the same piece of source material. Her pupils, at the end of her enquiry, were in a position to use their new knowledge, both of the events themselves and the historiography, to explain why two historians might interpret the past in different ways. It is worth pausing to reflect on what the process of enquiry design demanded of this particular teacher: she had to have a strong substantive knowledge of the period, a grasp on the historiography and an understanding of how pupils might be navigated through that complexity to some meaningful outcome.

The degree of curriculum and pedagogical thought that has to go into planning a sequence of lessons in which pupils will be brought to answer an enquiry question is clearly complex. For this question to be approached in a disciplinary manner, a teacher has to know not just the important facts, such as events 
and key individuals, but they also have to consider the manner in which the different interpretations of those facts will be used in their classroom. It is in this sense that pedagogical thought is historical thought. In planning an enquiry on the abolition of the slave trade, a history teacher has, for this to be a meaningful enquiry in a disciplinary sense, to engage with the historiography. In doing so, a teacher will come to grasp the disciplinary context in which the question is set; inevitably, they will also position themselves in relation to that question. From this, of course, will stem a number of pedagogical considerations: how will pupils be guided through the historiography? How will this be structured around the factual and conceptual knowledge that those pupils will need to answer the question? Indeed, a history teacher designing an enquiry in this situation will have to ask questions about the manner in which the academic debate becomes manifest in the enquiry that they construct. A large number of approaches to teaching an enquiry would be both historically and pedagogically defensible, yet such a defense requires the history teacher to have had engagement with the discipline. If, therefore, a discipline-based approach to teaching history is to be effected, it would seem necessary to consider what implications this has for how we understand the teachers whose task it is to put this into practice. It is for this reason, finally, that we must now turn to the question of teacher knowledge, in which, I suggest, the very possibility of such a disciplinary approach must be sought.

\section{The Knowledge of the History Teacher}

Arguably the most influential development in studies of teacher knowledge in recent decades is that carried out by Shulman [30,31]. Writing in an American context in which teachers were being criticized for a lack of subject expertise, Shulman sought to integrate subject knowledge into a model of teacher knowledge. According to Shulman, academic knowledge, defined as "content knowledge", is taken by the teacher and transformed into a form of knowledge which can be taught, which he named "pedagogical content knowledge". This is distinct from "content knowledge" as, in Shulman's words, it "goes beyond knowledge of subject matter per se to the dimension of subject matter knowledge for teaching [30]." At the heart of Shulman's model is an understanding that something happens to subject knowledge in the act of teaching. Bruner had previously argued that a transformation occurs when academic knowledge is converted, by non-teaching subject specialists and psychologists, into a curriculum ready to be taught by classroom teachers [32]. Shulman adopted transformation as a concept, but saw it as occurring in the cognitive acts of teachers. This interpretation, that the intellectual act of knowledge transformation occurs as part of, rather than prior to, the act of teaching, showed the critical importance of subject knowledge in teaching. As Shulman and Sherin later argued, "teaching and learning-to-teach must be viewed in discipline-specific perspectives [33]." The desire to see teacher knowledge in such disciplinary terms has subsequently attracted many who, though in many cases modifying Shulman's original model, have nevertheless accepted the underlying principles behind pedagogical content knowledge [34].

Despite, or possibly because of, Shulman's influence, his model has attracted a wide range of critics. Two of the most powerful critiques have challenged the manner in which Shulman incorporated disciplinary knowledge into his model. McEwan and Bull rejected Shulman's model on the basis that pedagogical content knowledge cannot be understood to be qualitatively different from content knowledge [35]. McEwan and Bull were arguing that there is no distinction, of the kind Shulman 
suggests, behind content knowledge and pedagogical content knowledge. This critique has important implications for understandings of teacher knowledge. If one were to remove the distinction between content knowledge and pedagogical content knowledge in our understanding of teacher knowledge, then one has to incorporate the epistemological problems inherent in an academic discipline, such as those identified in historical study, into that model. A second critique, which drew upon this, is advanced by Ellis [36]. He challenged the psychological basis of pedagogical content knowledge which did not, he argued, sufficiently reflect the way that "individual knowledge always stands in relation to a community of practice that evaluates its claims to justification and truth [36]." Ellis was arguing that subject knowledge is more problematical due to its social characteristics, and that this dimension could not be incorporated into Shulman's understanding of pedagogical content knowledge.

It would seem that Shulman's distinction between "content knowledge" and "knowledge for teaching" might not be sustainable in the light of demands to move away from "nation-building" or "skills-based" conceptions of history education and towards a situating in which classroom history is founded upon a socially- and temporally-understood discipline. As outlined in the examples above, the knowledge called upon by history teachers in designing such a curriculum and in teaching it cannot be reduced to "content knowledge", but instead depends upon positing a more complex relationship between a history teacher and the academic discipline of history. Given the importance of these teachers in effecting curriculum models and pedagogical practices, it would seem strange not to emphasize the centrality of teacher disciplinary knowledge if further progress along these lines is to be made. Yet, it would seem, existing models of teacher knowledge are not sufficiently robust for explaining the relationship between a history teacher and the discipline of history.

A number of possible alternative models might be advanced, all of which are in need of further research. One way of theorizing the relationship between a history teacher and the academic discipline would be to understand the former as a member of the latter. Indeed, it was to this conclusion that McEwan and Bull were led in criticizing pedagogical content knowledge, arguing that "teachers and scholars must be counted as part of the same community, with the additional burden of responsibilities that such membership entails [37]." It is tempting, at first, to think of history teachers as being full members of the disciplinary community; in the UK, most specialist history teachers received disciplinary training as undergraduate or postgraduate students, and entrants to the profession are the most qualified by degree result [38]. With a few exceptions, however, most history teachers are not active participants in the disciplinary community. They do not, for example, publish articles in academic journals, give conference papers or participate in teaching seminars in universities. For this reason, it is difficult to understand history teachers as being members of the disciplinary community: a more complex understanding of the relationship between a history teacher and their discipline is required.

Seixas went some way towards describing how this relationship might be construed. He argued that teachers form "a bridge between communities, extending outward to historians in one direction and to students in another [39]." History teachers, on this conception, are not so much members of the disciplinary community, but they do form the connection between that community and the pupils in their classroom. One way in which this might be understood is as a process of embodiment and representation. Take, by way of example, the way in which history teachers use the publications of the disciplinary community, rather in the way that Foster did in the example outlined above. Bingham, in 
considering his own practice, argued that "I act as a spokesperson of the book that I may or may not have read... I also push the book this way or that as if I am one of its chapters [40]." In this sense, the history teacher becomes the vocalization of the discipline, yet not in the sense of a ventriloquist's dummy, blindly repeating what they have read. In quite a literal sense, the teacher re-presents the discipline through their own interpretative faculties.

This does, of course, raise the question of why any particular history teacher's re-presentation of a product of the disciplinary community might be understood in some sense as authoritative. Muller answers this question by arguing that "the condition for a teacher being an authoritative pedagogical agent is, at the minimum, an internalized map of the conceptual structure of the subject, acquired through disciplinary training... In other words, the conditions for teachers to be able to induct pupils into strong internal grammar subjects is that they themselves already stand on the shoulders of giants, that they can speak with a disciplinary grammar [41]." A teacher can re-present disciplinary knowledge because, for Muller, they understand the rules and concepts that hold that discipline together. Having experienced disciplinary training, and thus having an understanding of disciplinary practices, teachers are able to serve as the embodiment of the discipline for their pupils. They become, at the front of their classroom, the discipline incarnate. Pupils, in this situation, submit their work not to the discipline of history per se, as Popper's Crusoe was expected to do, but rather to the discipline as embodied by their teacher. It would see a requirement of a history teacher who wishes to serve in this role that they have previously participated in the disciplinary community, most probably through academic training; arguably, history teachers might be expected to continue to engage with the discipline throughout their career if they wish to continue to be its representative in their classrooms.

\section{Conclusions}

Within the published discourse of the history education community, there would seem to be an increasing acceptance that the most appropriate way in which to develop the teaching of history in schools is by founding it upon the discipline of history. This, it would seem, allows history teachers to escape the Scylla of a single national grand narrative and the Charybdis of a skills-based approach that reduces the study of history to a consideration of the process by which this might be affected. Yet in accepting the importance of centering school history around the academic discipline, it would appear necessary to reflect the social and temporal nature of the discipline in the classroom, particularly through incorporating a historiographical dimension into what pupils study. For this to work, the teachers who design their enquiries need to be understood to exist in a relationship with the discipline of history that allows them to act, in Muller's terms, as "authoritative pedagogical agents". A history teacher's authority appears not to stem from being a direct member of the academic discipline, given that very few history teachers are such participants; one possible alternative model might frame this relationship around a teacher's ability to "embody" the traditions and practices of the discipline. Further work to develop such a model is undoubtedly required. If, however, such a model is to be predicated on an understanding that disciplinary concepts are crucial tools for the process of enquiry- and lesson-design, then, I would argue, it must be necessary to incorporate into that model the manner in which a history teacher stands in a temporal and social relation to the disciplinary community. 


\section{Acknowledgements}

My thanks go to Christine Counsell and Philip Gardner for discussions about the issues herein discussed and to the reviewers for their helpful comments.

\section{References and Notes}

1. Hansard, H.L. Publications on 20 October 2011; Volume 731, column 404. Available online: http://www.publications.parliament.uk/pa/ld201011/ldhansrd/text/111020-0001.htm\#1110203300 0622(accessed on 28 September 2012).

2. Gove, M. All Pupils will Learn Our Island Story. Presented at Conservative Party Conference, Birmingham, UK, 3-6 October 2010.

3. Cannadine, D.; Keating, J.; Sheldon, N. The Right Kind of History; Palgrave Macmillan: Basingstoke, UK, 2011.

4. Taylor, T.; Guyver, R. A review essay on the history wars: Ten case studies in controversy. Int. J. Hist. Teach. Learn. Res. 2011, 10, 68-72.

5. Parkes, R.J.; Vinterek, M. History curriculum, geschichtsdidaktik, and the problem of the nation. Educ. Sci. 2012, 2, 54-55.

6. Calder, L. Uncoverage: Toward a signature pedagogy for the history survey. J. Am. Hist. 2006. Available online: http://www.journalofamericanhistory.org/textbooks/2006/calder.html (accessed on 28 September 2012).

7. In particular I would cite the work carried out, inter alios, by Peter Lee and Denist Shemilt in the United Kingdom.

8. Newton, D.P.; Newton, L.D. Knowing what counts in history: Historical understandings and the non-specialist teacher. Teach. Hist. 1998, 92, 42-45.

9. Carlgren, I. Professionalism and teachers as designers. J. Curric. Stud. 1999, 31, 43-56.

10. Counsell, C. Disciplinary knowledge, the secondary history curriculum and history teachers' achievements. Curric. J. 2011, 22, 201-225.

11. Tosh, J. The Pursuit of History, 3rd ed.; Pearson: Harlow, UK, 2002; p. 7.

12. McAleavy, T. The uses of sources in school history 1910-1998: A critical perspective. Teach. Hist. 1998, 91, 10-16.

13. Cannadine, D.; Keating, J.; Sheldon, N. The Right Kind of History; Palgrave Macmillan: Basingstoke, UK, 2011; pp.160-166.

14. Counsell, C. Historical Knowledge and Historical Skill: The Distracting Dichotomy. In Issues in History Teaching; Arthur, J., Phillips, R., Eds.; Routledge: Abingdon, UK, 2000.

15. Foster, S.; Ashby, R.; Lee, P. Usable Historical Pasts: A Study of Students' Frameworks of the Past; Full Research Report RES-000-22-1676; Economic and Social Research Council: Swindon, UK, 2008.

16. Lee, P. "Walking backwards into tomorrow": Historical consciousness and understanding history. Int. J. Hist. Teach. Learn. Res. 2011, 10, 41.

17. Howson, J. Potential and pitfalls in teaching "big pictures" of the past. Teach. Hist. 2009, 136, 33. 
18. Seixas, P. Benchmarks of Historical Thinking: A Framework for Assessment in Canada; Centre for the Study of Historical Consciousness University of British Columbia: Vancouver, Canada, 2006.

19. Riley, M. Into the key stage 3 history garden: Choosing and planting your enquiry questions. Teach. Hist. 2000, 99, 8-13.

20. Gibb, N. Soon History Will Come Alive again in Class. Daily Telegraph, 22 October 2012.

21. Durkheim, E. Hierarchical Knowledge Structures and the Canon: A Preference for Judgements. In Language, Knowledge and Pedagogy: Functional Linguistics and Sociological Perspectives; Christie, F., Martin, J.R., Eds.; Continuum: London, UK, 2007.

22. Popper, K. The Open Society and Its Enemies: Hegel and Marx; Routledge: Abingdon, UK, 2003; Volume 2, pp. 242-243.

23. Lave, J.; Wenger, E. Situated Learning: Legitimate Peripheral Participation; Cambridge University Press: Cambridge, UK, 1991.

24. Wheelahan, L. How competency-based learning locks the working class out of powerful knowledge: A modified Bernsteinian analysis. Br. J. Sociol. Educ. 2007, 28, 637-651.

25. Skinner, Q. Visions of Politics: On Method; Cambridge University Press: Cambridge, UK, 2002; Volume 1, p. 100.

26. Coupland, R. The British Anti-Slavery Movement; Oxford University Press: Oxford, UK, 1933.

27. Williams, E. Capitalism and Slavery; University of North Carolina Press: Chapel Hill, NC, USA, 1944.

28. Drescher, S. Whose abolition? Popular pressure and the ending of the British slave trade. Past Present 1994, 143, 136-166.

29. Foster, R. Passive receivers or constructive readers: Pupils' experiences of an encounter with academic history. Teach. Hist. 2011, 142, 4-13.

30. Shulman, L.S. Those who understand: Knowledge growth in teaching. Educ. Res. 1986, 15, 4-31.

31. Shulman, L.S. Knowledge and teaching: Foundations of the new reform. Harv. Educ. Rev. 1987, 57, 1-22.

32. Deng, Z. Transforming the subject matter: Examining the intellectual roots of pedagogical content knowledge. Curric. Inq. 2007, 37, 279-295.

33. Shulman, L.S.; Sherin, M.G. Fostering communities of teachers as learners: Disciplinary perspectives. J. Curric. Stud. 2004, 36, 135-140.

34. Turner-Bisset, R. The knowledge bases of the expert teacher. Br. Educ. Res. J. 1999, 25, 39-55.

35. McEwan, H.; Bull, B. The pedagogical nature of subject matter knowledge. Am. Educ. Res. J. 1991, 28, 316-334.

36. Ellis, V. Subject Knowledge and Teacher Education; Continuum: London, UK, 2007.

37. McEwan, H.; Bull, B. The pedagogical nature of subject matter knowledge. Am. Educ. Res. J. 1991, $28,333$.

38. Smithers, A.; Robinson, P.; Coughlan, M. The Good Teacher Training Guide 2012; Centre for Education and Employment Research University of Buckingham: Buckingham, UK, 2012; pp. 27-28.

39. Seixas, P. The community of inquiry as a basis for knowledge and learning: The case of history. Am. Educ. Res. J. 1993, 30, 316. 
40. Bingham, C. Authority is Relational; State University of New York Press: Albany, NY, USA, 2008; p. 26.

41. Muller, J. On splitting hairs: Hierarchy, knowledge and the school curriculum. In Language, Knowledge and Pedagogy: Functional Linguistics and Sociological Perspectives; Christie, F., Martin, J.R., Eds.; Continuum: London, UK, 2007; pp. 82-83.

(C) 2012 by the authors; licensee MDPI, Basel, Switzerland. This article is an open access article distributed under the terms and conditions of the Creative Commons Attribution license (http://creativecommons.org/licenses/by/3.0/). 